\title{
Ethno-Linguistic Processes in a Globalizing World: The Study of Cultural and Language Behavior of the Kazakhstani Repatriates in the Socio-Linguistic Aspect
}

\author{
Sholpan Zharkynbekova, Assel Akzhigitova, Lyazzat Dalbergenova \\ L.N. Gumilyov Eurasian National University, Astana, Kazakhstan
}

\begin{abstract}
The current linguistic situation in the former Soviet Union over the past decade requires the development of new approaches to cultural and language issues, a new methodological framework for the research and theoretical generalization of cultural, linguistic, socio-linguistic, and ethno-linguistic processes. The Republic of Kazakhstan is multinational and multireligious region. This situation has evolved over several centuries, and is inextricably linked to the particular historical development of the country. Kazakhstan is now regarded not only as one of the models of interaction but also interpenetration of different cultures. It is undergoing renovation in the field of international relations. A new area of ethno-cultural interaction were ethnic Kazakhs, who are settling down in the country, increasing the mosaic structure of settlement and creating a new situation in the system of relationships. In this paper, in order to determine the attitude towards Kazakh, Russian, and other languages, linguistic preferences of respondents the questionnaires and interviews were carried out. As immigrants there were selected the Kazakh repatriates, immigrants from China, Mongolia, Russia, and other countries. The research results reflected that interiorization of language identity of immigrant respondents is a complicated and ambiguous process due to the linguistic, social and historical, psychological, and cultural peculiarities.
\end{abstract}

Keywords: language situation, language policy, ethno-linguistic processes, the functioning of languages in Kazakhstan, migration

\section{Introduction}

Language situation in any multiethnic state differs by spectrum of its complex and sometimes unique models in each case. This versatility can be explained by socio-linguistic, ethno-linguistic, political, socio-economic, and other factors.

According to the Kazakhstani scientists and linguists E. Suleimenova, N. Shaimerdenova, and D. Akanova (2007), "Ethno-linguistic landscape of modern Kazakhstan is characterized, on the one hand, by a high degree of

Sholpan Zharkynbekova, professor, Dean of the Faculty of Philology, L.N. Gumilyov Eurasian National University.

Assel Akzhigitova, Ph.D. student, Department of Theoretical and Applied Linguistics, Faculty of Philology, L.N. Gumilyov Eurasian National University.

Lyazzat Dalbergenova, Ph.D. student, Department of Theoretical and Applied Linguistics, Faculty of Philology, L.N. Gumilyov Eurasian National University. 
linguistic diversity, on the other-by the fact that two ethnic groups (Kazakh and Russian) dominate quantitatively over all other ethnic groups, increasing demographic non-equilibrium and unbalanced linguistic situation" (p. 14). The Kazakh language secured in the adopted July 11, 1997 Law "On Languages in the Republic of Kazakhstan" (Article 4) (The Law On Languages, 1997), and certainly, is now a strong language, demographically and functionally. Announced in the basic documents the status of the Russian language reflects its demand in Kazakhstan as a carrier of a significant amount of scientific and cultural information. Priorities for the new language policy in independent Kazakhstan were determined by the desire of meeting the needs of multi-ethnic population, particularly to take into account linguistic, demographic, and political situation and maintain stability of international relations.

Among a number of important factors that influenced the language situation in Kazakhstan named by Suleimenova as follows: (1) the departure from the country, as a rule, of socially active and emigrational mobile people, resulting in dramatically reduced number of Russian speakers, many of Diaspora (Russian, Ukrainian, Belarussian, and some others) were characterized by low demographic indicators; (2) a large influx of Kazakh returnees, a considerable part of possessing no stable reading and writing skills in the Kazakh language not speak to a sufficient degree Russian language; and (3) continuing to grow the Turkic-speaking part of the population as due to increasing of the proportion of Kazakhs (natural increase, replacing demography), and due to high birth rates, migration into the country, and others, as a rule, compactly living Uzbeks, Uighurs, Turks, and Azerbaijanis. Kazakhstan, as well as, all the CIS (Commonwealth of Independent States) countries is becoming more mono-ethnic (Suleimenova, 2010).

Migration and other integration processes in the country and abroad are directly reflected on the status and condition of languages, functioning in the territory of Kazakhstan. The complexity of addressing the consequences of migration not only in the fact that it affects the fate of specific individuals, but also in the fact that its decision was linked to interstate relations, political stability, and national security and state receiving repatriates and, of course, pursued in the country language policy and language planning.

All of the above determine the importance of studying the socio-cultural and linguistic adaptation and integration into Kazakh society of such categories of citizens as immigrants ${ }^{1}$.

\section{Migration Processes in Kazakhstan and Their Influence on the Ethnic Composition}

The current socio-linguistic situation reflects political, economic, cultural, and social changes in historical development of Kazakhstan. The key factors that influenced sociolinguistic space of Kazakhstan, ethno-linguistic identity and vitality in particular, as well as the peculiarities of language functioning in Kazakhstan are the demographic factors and sociopolitical and historical-cultural reasons of emigration of other ethnic groups to Kazakhstan. A significant role in the history of the former Soviet Union belongs to the forced settlement of peoples.

Since the late 19th century till the middle of the 20th century, the ethnic composition of Kazakhstan was

\footnotetext{
1 In the legal documents of the Republic of Kazakhstan, this category of citizens was called the "oralmans" that in translation from the Kazakh language means "returnees". In the Law of Republic of Kazakhstan "On migration" from December 13, 1997, this term is understood as follows: "foreigners or stateless persons of Kazakh nationality, permanent residence at the time of acquisition of the sovereignty of the Republic of Kazakhstan beyond its borders and arrived in Kazakhstan for permanent residence".
} 
considerably reshaped primarily owing to the Bolsheviks' policy, and aimed at forced deportation of the whole nations in the 1930s-1950s, the famine in 1931-1932, and also the labor migration mostly of Russians, Ukrainians, and Byelorussians. Consequently, a peculiar area of ethnic minorities appeared in Kazakhstan when the Germans, Ingushs, Chechens, Koreans, Karachai, Kalmyks, Balkars, Crimean Tatars, Greeks, Poles, Finns, and Meskhetian Turks underwent a total deportation. The deported ethnic groups totaled 1.2 million in the 1930s and 1940s.

That demographic context based on the policy of Russification negatively affected the population size of the Kazakhs which, in its turn, led to lowering the role of the Kazakh language. In 1929, the Kazakhs constituted a half of the total population (58.2\%) and in the further 33 years the population size was diminished to only $50 \%$. In 1959 , the number of the Kazakh population decreased to $30 \%$ of the total number of population, most of which were rural residents. The share of Kazakhs in the urban population comprised only $20 \%$. On the contrary, the Slavic groups prevailed in urban areas (Smagulova, 2008). The Russians consolidated not only a superior demographic position; they were also dominant in political, economic, and cultural aspects. As Laitin (1998) noted, the percentage ratio of the Kazakhs in the leading job positions comprised $46.6 \%$, and occupancy in administrative positions was $6.7 \%$. The share of non-Russian scientific workers constituted $21.4 \%$ in 1960 and $29.8 \%$ in 1973 in the intellectual space. Such an ethnic differentiation of labour force determined a comparative prestige of certain ethnic groups. A comparatively low quantity of Kazakh-language social and educational institutions and prevalence of the Russians in urban areas of Kazakhstan led to language assimilation among the Kazakhs. The share of the Kazakhs who spoke fluent Russian increased from $41.6 \%$ in 1970 to $50.6 \%$ in 1979 and comprised $62.8 \%$ in 1989 , while only $1 \%$ of the Russians could speak Kazakh. Therefore, as Smagulova (2008) stated, "This asymmetrical bilingualism reflected the ethnic stratification of the Soviet Kazakhstan, where Kazakh-speakers found themselves dominated politically, economically, and culturally, and threatened demographically" (pp. 445-446).

Such an organized and coercive character of migration (a large inflow of monolingual Russians and their influence on political, economic, and cultural life) in the Soviet time, and also the language policy of Russification shaped a specific linguistic situation in Kazakhstan when the Russian language became a principal means of communication among the nations, ipso facto restricted the status and socio-linguistic functions of the Kazakh language.

Large-scale internal and external migrations took place due to major political changes in independent Kazakhstan. The most intense process of foreign migration occurred on the first three years after the collapse of the Soviet Union. Within 1992-1994, 1.125 thousand people emigrated from Kazakhstan, and 73\% of them migrated to the CIS countries. During that period, 343 thousand people came to Kazakhstan, $91 \%$ of them from the CIS countries (Smailov, 2001).

It should be noted that out of 13 million of Kazakhstan's population in 1970, 4.2 million were Kazakhs and 5.5 million were Russians. In 1979, with the population of 14.7 million people, Kazakhs constituted 5.3 million people and Russians were 5.99 million people. According to the 2009 Census with the population of 16.2 million people, Kazakhs comprised 10.06 million people and the Russians were 6 million people. Hence, the migration processes have led to radical changes in ethnic composition of the country's population. The Kazakhs who constituted a third of the total population 30 years ago have become the majority and their share in the total population constitutes $63.1 \%$, the Russians-23.7\%, the Uzbeks-2.9\%, the Ukrainians-2.1\%, the 
Uigurs- $1.4 \%$, the Germans-1.1\%, and other ethnic groups- $4.5 \%$ (Smailov, 2001).

Thus, the social, political, and economic changes in the country after the collapse of the Soviet Union have reshaped the demographic situation of Kazakhstan. During the period from 1999 to 2009, the number of the Russians fell by $15.3 \%$ and the Ukrainians by $39.1 \%$, and the number of the Germans dramatically fell almost as three times by $62.7 \%$.

On the other hand, there has been an increase in the number of Turkic-speaking people. During the years of independence of the Republic of Kazakhstan (exactly since 1991), 806,880 ethnic Kazakhs have returned to their Motherland. The share of the Kyrgyzs have considerably increased and comprised $10.3 \%$; the growth rate of the Tajiks and the Dungans have been $43.3 \%$ and $40.6 \%$ respectively. The share of the Turks and emigrants from Uzbekistan has also increased to $27.7 \%$ and to $23.3 \%$ respectively (Smailov, 2010). High rates of percentage increase in emigrant inflow might be interpreted by a comparative economic, political, and social stability in Kazakhstan. According to expert judgments, $70 \%$ of internal migration went to the shift "from village to city". The main reason for this is an economic one. A city attracted the population by its active development and the opportunity of high income. In addition, youth internal migration is related to issues of getting education. The main centers of "gravity" of rural migrants are Almaty and Astana.

Since 1995, Kazakhstan has faced the tendency of decrease in the number of migrants leaving the country and, as a result, the decreasing negative balance in migration. Thus, the number of emigrants in 1999 fell to 2.9 times as compared to 1994, and the negative migration balance fell to more than three times. There is a positive balance of migration with Uzbekistan, Turkmenistan, and Tajikistan, whereas a negative balance is still present with Russia, the Ukraine, and Byelorussia. The major mass departure of migrants from Kazakhstan, according to the statistical data for 1998-1999, has been directed to the CIS countries (77\%) as it has taken place before, among them 91\% migrated to the Russian Federation. The ethnic composition of the emigrants is dominated by the Russians (over $55 \%$ ), the Germans (20\%), the Ukrainians (10\%), the Tatars (2.4\%), and the Byelorussians (2.1\%).

Nowadays, the language policy of Kazakhstan reflects the demographic and linguistic complexity of the phenomenon. A noticeably growing role of the state language in consolidating the society and fostering patriotism is obvious; slowly but steadily, the lingual sphere of the Kazakh language is being built. Along with this, all activities aimed at raising the status of the Kazakh language to the national level are supported by the steps on providing favorable conditions for the other languages without ousting any of them from the informational-lingual area in the country. The Russian language also holds strong positions in Kazakhstan.

The issues of consideration of ethno-linguistic consciousness connected with the life of ethnic minorities is becoming significant since the functional status of many languages of minor ethnic groups of the former USSR (The Union of Soviet Socialist Republics) has dramatically fallen as affected by the circumstances, and in some cases, even their existence has become endangered.

\section{The Kazakhs’ Repatriation to the Historic Homeland}

Government policy in respect of the compatriots living abroad, namely, work on returning to their historic homeland of ethnic Kazakhs in Kazakhstan has increased markedly in the post-perestroika period. A nationwide importance of the process of return of ethnic Kazakhs to Kazakhstan is high and lies in the historical, socio-economic, political, demographic, ethno-psychological, and even population-genetic enrichment of the 
Kazakh people ("The Long-term Development...", 1997). This is undoubtedly due to the socio-economic changes in the country that has strengthened the immigrants desire to return to their historic homeland. Note, however, that not all ethnic Kazakhs ready to return. However, it should be noted that not all ethnic Kazakhs are ready to return. Thus, according to a survey conducted by Kazakh scientists, $90 \%$ of Kazakhs from Samara region are not ready to move to Kazakhstan. Among the reasons for the reluctance to return home there were called a high standard of living in the Volga region, the ignorance of the native (Kazakh) language, breaking cultural and family ties created because of the state border, the lack of regular information from their historical homeland (press, TV, book literature) (The Kazakh Diaspora..., 2009, p. 27).

Thus, immigration of ethnic Kazakhs from abroad contributes to a growth of the general population, as well as increase of the proportion of indigenous people in the general population. Repatriates make a certain contribution to the development of national literature, art, music, science, education, and business in the homeland (Baltabayeva, 2010). It must be recognized that the repatriation of a significant part of Kazakhs also contributes to the formation of a single Kazakh speaking environment in Kazakhstan, which is parallel with the creation of favorable conditions for development self-consciousness of repatriates in the aspect of language and culture. This means repatriates have enormous impact on the process of language planning of the state.

According to Population Census in 2009, since gaining independence to the Republic of Kazakhstan from far and near abroad have moved 210,225 families of ethnic Kazakhs (824,170 people). The main flow of immigrants coming from countries where there is a significant Kazakh Diaspora in the first place was Uzbekistan (126,790 families-494,565 people), China (25,764 families-85,487 people), Mongolia (22,124 families-110,856), and Turkmenistan-16, 232, from Russia-11,065 and Tajikistan-2,756 families (Smailov, 2010).

For many repatriates, an important part of the adaptation and integration processes to Kazakh society is knowledge of languages. Kazakhstan due to its territorial integrity encompasses a very diverse geographic landscape, resulting in development of different linguistic situations in different regions. For example, the certain difficulties experience immigrants from China, Mongolia, Tajikistan, Turkmenistan, and Uzbekistan, living in the northern regions of the country where the Russian language is dominant in international communication of the population. On the other hand, difficulties arise among repatriates arriving from Russia, many of whom do not speak the Kazakh language. The results of these contradictions are quite predictable: the immigrants, rather than actively interacting with the population to learn the new standards, lead alienated way of life, forming a localized community with their separate worldview.

\section{Methodology}

The methods used in surveying were questionnaires, interviews, and biographical method (language biography). The number of respondents amounted to 1,000 people aged 16 to 60 years old. The survey covered the repatriates who arrived to Kazakhstan from China, Mongolia, Uzbekistan, Tajikistan, Turkmenistan, and Russia. Considering that from these countries as of percentage of returned to their historic homeland makes a large number of repatriates, in accordance with the general population, among oralmans from Uzbekistan were interviewed 600 people, from Mongolia—135 people, from China - 104 people, from Turkmenistan—77 people, from Russia -53 people, and from Tajikistan -31 respondents. 
The questionnaire was compiled in the Kazakh and Russian languages, the questions were open and closed types, and consisted of the following units: (1) data of participants (gender, age, marital status, education, nationality, and period of stay in Kazakhstan); (2) attitude to Kazakh and Russian languages; (3) the choice of language in different situations and the frequency of its use; (4) the degree of language proficiency, in which respondents evaluated the knowledge of a particular language; and (5) additional questions that affect civil position of the respondents, their socio-economic, political, and religious position.

For each question were proposed some variants of answers (from 2 to 5 options). For the analysis of research results was applied mathematical and statistical processing by using SPSS (Statistical Package for Social Sciences) and was carried out qualitative analysis.

Questioning was held during the period from January 2009 to December 2010 in six regions of Kazakhstan (North Kazakhstan, East Kazakhstan, Mangystau, South Kazakhstan, Akmola Oblasts, and Astana city).

Expected results are the creation of the concept of sociolinguistic development of Kazakhstan including elements of the language forecasting and planning.

\section{Results}

Based on this study, we identified four levels of Kazakh and Russian language competence of returnees. The first group consisted of individuals whose dominant was Kazakh language, competence in the Russian language - weak, the second and third groups - with uneven levels - social and adequate communication in the Kazakh and Russian languages, the fourth — with dominant Russian language and competence in Kazakh at the level of understanding and everyday communication.

At the next level of classification, we have added such elements as a willingness to join communication with a native speaker of other language, opinion on the language policy of the state, etc.. As a result, we obtained four types of language personalities of returnees which can be summarized as follows in terms of socio-cultural and linguistic orientation.

The first type includes those, who: (1) speak only Kazakh language; (2) refuse to participate in communication with the use of the Russian language; (3) consider that all official and political life and the whole sphere of everyday life should be in the Kazakh language; (4) consider that all people of Kazakhstan should speak only the Kazakh language; (5) consider it necessary to remove from the compulsory school curriculum such subjects as Russian language and literature; and (6) believe that the Russian language negatively affects ethno-linguistic identification of personality, patriotism of youth.

Thus, the first type is Kazakh language speaking individuals considering the Kazakh language not only as a guarantee of achieving the goal, but also as more prestigious. There is no doubt that Kazakh language for them is an important factor for shaping the ethnic identity, a channel of its transmission and expression. But for them there exists kind of significant repulsion, alienation from the Russian language and cultural space, demonstrated in communication (especially with those who mostly speaks in Russian):

... Сондықтан мектептегі орыс тілі мен орыс әдебиетін алып тастау керек. Бұл қазақ ұлтының тағдырын өзгертетіне сенемін..._... And therefore, we must exclude the Russian language and literature from the school disciplines. I believe that this will affect the fate of the Kazakh people... (worker of Culture, age 33, moved from Tajikistan in 2006) 
Қазақ елі екенін білдіріп, орыс мектептер емес, оның орнына қазақ тілі мектептерін көбейту, орыс тілі әдебиеттерін қазақ тіліне аударып, орыс нұсқасын жойып жіберу. Жалпы бала-бақшадан бастап орыс тілін азайту, тіпті күшінен қалдыру керек....-To demonstrate that this is - the Kazakh people, it is necessary to increase the number of not Russian, but Kazakh schools, it is necessary to translate books written in Russian language to the Kazakh language, and to destroy the Russian version. It is necessary to reduce the Russian language from the kindergarten, and even remove at all... (social worker, 41, moved from Mongolia in 2007)

The second type refers to repatriates who: (1) speak mostly Kazakh language; (2) participate in communication and in the Kazakh and Russian languages; (3) consider it right that the state should be formed by a single Kazakh language atmosphere; (4) consider it necessary to expand the social functions of the state language in different areas of communication; (5) sufficiently tolerant of the Russian language, considering it a prestigious and important for learning and making some efforts for its early learning; and (6) adhere to the view that knowledge of languages is the key to success, but above all, one need to master his/her own language.

This type includes basically those who live in Kazakhstan more than 5-6 years, assimilating socially, culturally, and linguistically. The qualitative and quantitative analysis of languages functioning's characteristics in the linguistic community of the repatriates shows that this type together with Kazakh language aspires to the active Russian language acquisition:

... Дәл қазіргі күні менің елге оралғаныма 6 жыл болса да, орыс тілін әлі де жетік біле алмағаныма өкінемін. Себебі мен осы 6 жыл ішінде неше түрлі ойда жүрдім. Осы ойларыма қысқаша тоқталып өтсем: ең бірінші мен келген кезде қазақша сөйлемегендерге қатты ашуланатынмын, орыс тілін жек көрдім сол себепті мен орыс тілін үйренгім келмеді. Енді оның дұрыс емес екендігіне көзім жетті. Себебі орыс тілі менің туған тілім болмаса да мен оны білуім керек, өйткені ол ең маңызды тілдердің қатарына жатады...-Even if have already passed 6 years since my stay in Kazakhstan I regret very much that have not studied the Russian language to the end. All these 6 years I have had different thoughts. Would like to share these thoughts: When I came here, was very angry with those who did not speak Kazakh, hated Russian, and therefore have not studied it. Only now I realize that it was wrong. Even if the Russian language is not my native language, I must know it, because it is one of the most important languages... (social worker, aged 35, moved from Mongolia in 2003)

The third type refers the type of repatriate who: (1) speak Kazakh and Russian languages; (2) participate in communication in the Kazakh and Russian languages; (3) consider it right that in the country at official level on a par with the Kazakh language, Russian language is used; (4) consider that people should master at least two languages-Kazakh and Russian; (5) refer positively to the study of Russian language and literature in the school; and (6) adhere to the view that knowledge of languages is the key to success, but recognizes the need for mastering of, first of all, native language.

Thus, the third type includes those who sufficiently speak both languages, and experience no difficulty in adaptation. This type can be defined as deliberately bicultural. The most important feature of ethno-linguistic consciousness of this type, in our opinion, is that it does not involve the displacement of one language/culture due to the acquisition of another. In the case of bilingualism, within this type of language personality native language and target language do not compete with each other. They strive to bring to a possible perfect level of knowledge the new languages and cultures, without losing the original language and cultural competence:

... Я родился в России. Всю сознательную жизнь прожил в России. Мои дети разговаривают на казахском языке, но слабо. Там они учились на русском языке. Родным языком считаю казахский язык...Я считаю, что нужно знать и другие языки...Нужно разговаривать и на русском, и на казахском язык.-... I was born in Russia. 
All my conscious life I lived in Russia. My children can speak Kazakh, but poorly. In Russia they studied in Russian. I consider the native language to be Kazakh language... I think it is necessary to know other languages as well... It is necessary to speak Russian and Kazakh languages... (Duisenov Amangeldy, born in 1950, he moved to Kazakhstan in 2009 from Russia)

The fourth type includes those who: (1) speak Russian; (2) participate in communication with the use of Russian or another language; (3) consider to have two native languages-Kazakh and language of the country where they lived until repatriation (for example, Russian and Tajik languages); (4) support the status of Russian as an official; (5) strongly support the presence of the Russian language in official and political spheres as well as in everyday life; and (6) ambivalently and ambiguously identify themselves, as faced with a choice of "native" language between autochthonous and "acquired".

For this category of the repatriates, the language competence in Kazakh language is poorly expressed - more than half of the asked respondents either understand but cannot explain in Kazakh or do not speak it at all. Among theirs familiars and relatives they prefer to communicate in Russian language predominantly rather than in Kazakh or this alternative is not found and they use Russian language for the establishing communication contacts. They prefer to think in Russian. In future, they would like to perfect their knowledge in Kazakh language considering it to be native, although there were found such respondents who considered Russian as their native language or could not decide on this item. For this type of repatriates, the awareness of the special language significance as the ethnos integrator is much weaker. Most likely, the problem of language loss is not important for them and is largely considered abstractedly:

... Казахским языком владею немножко, я только понимаю, не пишу и не говорю. В семье общаемся на русском языке. Когда жили в Омске, общались тоже только на русском. Учился в русской школе. Себя считаю казахом. Родной язык мой-русский. Вообще-то, два получается родных языка-казахский и русский. Просто русским я более или менее владею хорошо, и могу высказать себя только на русском языке.-I master Kazakh language a little bit, I just understand, I do not write and do not speak. Within family we communicate in Russian. When I we lived in Omsk, also spoke only in Russian. I studied at the Russian school. Consider myself Kazakh man. My mother tongue is Russian. In fact, I've got two native languages - Kazakh and Russian. Simply I speak Russian more or less well, and can express thoughts only in Russian. Native language is the one in which you grew up and learned to talk, which is more or less enjoyable, and on which you can communicate well. I think and speak only in Russian... (Barlybaev Askhat, immigrant from Russia);

... Считаю своим родным языком-казахский и русский... Потому что в базе у меня заложен русский язык... Я думаю на русском... с детства общаюсь на русском... Среди русских вырос... На казахском понимать-понимаю, но не пишу-... I consider as the native language Kazakh and Russian... Since as a basis I had Russian language... I think in Russian... since childhood... I communicate in Russian, grew up among Russian... As for Kazakh-I understand it, but do not write... (Daurenov Sabit, born in 1982, he moved from Russia in 2008)

Follows from the above, we see that respondents in this category have difficulties in forming their own linguistic identity, as in the family, and in other areas of communication was primarily used non-native (Russian, Uzbek, Tajik, or other) language.

\section{Discussion and Conclusions}

Thus, we see that if for some respondents language performs both functions (communicative and symbolic), then the other category of respondents-returnees, identity is based on the language only as a symbol of the unity of the people. This confirms the assumption that the level of identity is determined primarily by the preference of 
language rather than its actual use. The available share of unstable national and linguistic identity of returnees (mostly from Russia and Tajikistan) indicates that their personal relationship with the ethnic language to some extent been lost, but most of them still have vision for formal separation of ethnic languages as their native, associated with the desire to meet the social expectations.

For general language competence turned out to be significant factor the country of immigration: Most of the first group was immigrants from China and Turkmenistan, in the second group dominated immigrants from Mongolia, Uzbekistan, and Tajikistan, and the third formed exclusively Kazakhs returned from Russian.

All of the above convinces that the interiorization of linguistic identity of the respondents - returnees is a complex and multi-valued process, due to linguistic, social, historical, psychological, and cultural characteristics.

Undertaken in the country language policy, undoubtedly, should be aimed at improving the social, economic, and cultural life of all citizens in the country. And for oralmans, language situation needs to be as comfortable as its socio-cultural and economic status.

\section{References}

Baltabayeva, K. N. (2010). Linguistic adaptation of ethnic Kazakh-settlers from Russia and other countries in Kazakhstan: Similarities and features/language policy and social and legislative adaptation of immigrants: Problems, realization, perspectives/From the III International scientific and practical conference (Part I, p. 81). I. S. Karabulatova, G. S. Korepanova, \& A. P. Sunzova (Eds.). (Языковая адаптация в Казахстане этнических казахов-переселенцев из России и других стран: общее и особенности//Языковая политика и социально-правовая адаптация мигрантов: проблемы, реализация, перспективы//Материалы III Междунар. науч.-практ. конф., Ч.1., с.81 / Под ред. И.С. Карабулатова, Г.С. Корепанова, А.П. Сунцова). Tumen: Vector-BukJu.

Laitin, D. (1998). Identity information: The Russian-speaking populations in the near abroad. Ithaca, N.Y.: Cornel University Press.

Smagulova, J. (2008). Language policies of Kazakhization and their influence on language attitudes and use. The International Journal of Bilingual Education and Bilingualism, 11(3-4), 440-475.

Smailov, А. (Смаилов, А.). (Ed.). (2001). The results of the 1999 population census in the Republic of Kazakhstan (Kmozu переписи населения 1999 года в Республике Казахстан). Almaty: Statistics Agency of the Republic of Kazakhstan.

Smailov, A. (Ed.). (2010). The results of the 2009 population census in the Republic of Kazakhstan (Итоги переписи населения 2009 года в Республике Казахстан). Almaty: Statistics Agency of the Republic of Kazakhstan.

Suleimenova, E. (Ed.). (2010). Dynamics of the linguistic situation in Kazakhstan (Сулейменова, Э. Динамика языковой ситуации в Казахстане). Almaty: Qazaq Universiteti.

Suleimenova, E., Shaimerdenova, N., \& Akanova, D. (2007). Languages of Peoples of Kazakhstan. Astana: "Arman-PV". (Сулейменова, Э., Шаймерденова, Н., Аканова, Д. Языки народов Казахстана. Астана: Арман-ПВ).

The Kazakh diaspora in Russia: Modern state and the native language perspectives: Sociological study. (2009). (Ресейдегі қазақ диаспорасы ана тілінің қазіргі ахуалы және келешегі тақырыбына әлеуметтік зерттеу. Казахская диаспора России: современное состояние и перспективы родного языка: Социологическое исследование). Almaty: DKK .

The long-term development strategy of the Republic of Kazakhstan to 2030. (Electronic resource). (1997). Retrieved from http://www.akorda.kz

The Republic of Kazakhstan Language Legislation “On the languages in the Republic of Kazakhstan” (issued on 11 July 1997 № 151-1, with amendments entered by the Republic of Kazakhstan’s Law of 20 December 2004. № 13-III). (1997). (Закон о языках РК ‘О языках в Республике Казахстан’ (от 11 июля 1997 года № 151-1, с изменениями, внесенными Законом РК от 20 декабря 2004г. № 13-III)). 